\title{
TRADITIONAL VILLAGE SYSTEM - CASE STUDY FROM THE KREMPNA COMMUNE (POLAND)
}

\author{
IHOR KOZAK ${ }^{1,2}$, IVAN BALANIUK ${ }^{3}$, DIANA SZELENKO ${ }^{3}$, SERGIY BALANIUK ${ }^{4}$, \\ HANNA KOZAK ${ }^{5}$
}

${ }^{1}$ Department of Landscape Ecology, John Paul II Catholic University in Lublin, Konstantynów 1H, 20-708 Lublin, Poland; e-mail: modeliho@kul.lublin.pl

${ }^{2}$ Department of Biology and Ecology, Vasyl Stefanyk Precarpathian National University, Shevchenko str., 57, 76010, Ivano-Frankivsk, Ukraine

${ }^{3}$ Department of Accounting and Auditing, Vasyl Stefanyk Precarpathian National University, Shevchenko str., 57, 76010, Ivano-Frankivsk, Ukraine; e-mail: ifbalaniuk@gmail.com, dianashelenko@ukr.net

${ }^{4}$ Department of Marketing and Management, Vasyl Stefanyk Precarpathian National University Shevchenko str., 57, 76010 Ivano-Frankivsk, Ukraine; e-mail: serhio088@gmail.com

${ }^{5}$ Department of Nature Preservation, John Paul II Catholic University in Lublin, Konstantynów 1H, 20-708 Lublin, Poland; e-mail: hannakozak@kul.lublin.pl

Abstract

Kozak I., Balaniuk I., Szelenko D., Balaniuk S., Kozak H. Traditional village system - case study from the Krempna commune (Poland). Ekológia (Bratislava), Vol. 38, No. 1, p. 87-100, 2019.

The study was conducted within the actual area of Krempna commune in Jaslo county Podkarpackie voivodeship in Poland. Historical data and maps were analysed using the ArcGIS 10.3 program. The changes in the number of villages, householders and human population were presented. Religious composition for the year 1785 and ethnic composition for the year 1939 were evaluated. Only in the case of Ukrainian population, the Moran's test has shown dispersed distribution (Index Moran's for Ukrainians $=-0.478664 ; \mathrm{Z}=-1.684100 ; \mathrm{P}=0.092162$ ). The total number of householders increased from 915 in the year 1785 to 1,409 householders in the year 1939 and decreased to 349 in the year 1965 and 333 in the year 2018. The traditional village system (TVS) of Krempna commune was depopulated after World War II. As a result, the agricultural abandonment and forest succession developed. Class area (CA) of settlements decreased from 1174.02 ha in the year 1939 to 248.13 ha in the year 1965 and 240.2 ha in the year 2018, and CA of forests increased from $7,268.20$ ha in the year 1939 to $15,465.20$ ha in the year 1965 and $15,841.3$ ha in the year 2018. Villages that had begun the core of TVS together with tserkvas and chapels in the centre of village, roadside crosses and traditional private farms were lost. The scale and results of such changes are interesting for future research, mainly in terms of change in TVS infrastructure and culture.

Key words: land use, cultural landscape, dynamics, GIS.

\section{Introduction}

An important part of the world's landscapes were managed by local and indigenous communities (Stevens, 1997). Such cultural landscapes were based on a traditional village system (TVS) with centre-periphery zoning from houses, gardens, fields, mowed grasslands 
and grazed grasslands to forests. It is analogous to the ancient system with domus, hortus, ager, saltus and silva (UNESCO, 1999; Elbakidze, Angelstam, 2007). TVS carried traditional knowledge, innovations and practices of indigenous and local communities. Such systems were gained over long time and were adapted to the local culture and environment. They help to sustain production of various goods and services providing livelihoods safety and value of life. The TVS supplies to feature natural and ethnic cultural heritage and traditions (Angelstam et al., 2003; Agnoletti, 2006; Parrotta et al., 2006).

On the other hand, the TVS integrated economic, ecological and socio-cultural extent of landscapes in space and time (Bourguignon, 2006). Cultural heritage and traditional knowledge of TVSs have been accepted and promoted at an international level in a number of worldwide agreements (World Conference, 1982; European Landscape Convention, 2000; MCPFE, 2003). Nevertheless, the TVS with its feature cultural landscape were threatened by political, socio-economic and technological changes (Antrop, 2005; Angelstam, 2006).

The Krempna commune study region had landscape resources of high economic value and retained both cultural and natural biodiversities (Angelstam, 2006). This region was also home to ethnographic group of Ukrainians - Lemkos - who have been determining mountain landscapes for centuries and have created a rich economic (Denysjuk, 1938) and cultural heritage with 13 tserkvas.

The role of TVS in terms of Ukrainian Carpathians is evaluated in the context of sustainable forest management (Elbakidze, Angelstam, 2007). The analysis of the social and cultural aspects of TVS is a current issue and requires the development of new approaches.

Cultural landscapes in Krempna commune, of course, were related to the TVS, which is characterised by a specific zoning from the centre (building with the tserkvas) through farmland, hayfields, pastures and forests (Elbakidze, Angelstam, 2007) to the periphery. The understanding of the definition of the TVS lies in the fact that such a system united local communities, which for centuries created a rich Ukrainian cultural heritage (cultural and educational societies such as 'Ridna szkola', 'Prosvita', 'Sokil', tserkvas, schools, libraries, cooperatives and craft workshops), and adapted to mountainous conditions and the environment. The consequences of the loss of such a system require a more detailed study.

The results of depopulation of Krempna community were agricultural abandonment (MacDonald, 2000; Van Vliet, 2015) and loss of landscape attractiveness and landscape heterogeneity as well as its cultural heritage (Pazur et al., 2014).

Agricultural abandonment is widespread in the world (Cramer et al., 2008), including postsocialist countries of central and Eastern Europe (Kuemmerle et al., 2008; Lieskovsky et al., 2015). In post-socialist countries, agricultural abandonment dominates mainly after the year 1989. Some time earlier, this process occurred in Slovakia (in the years 1950-1970) and brought changes in agricultural land use structure (Masný et al., 2017). The agricultural abandonment led to a decrease in agricultural production and often also to rural migration (Muller et al., 2009).

But, in Krempna commune, we can observe the process of agricultural abandonment earlier. It happened after the deportation of Ukrainians - Lemkos - in the years 1944-1946 (Gil, 2004) and after the loss of TVS. Agricultural abandonment and expansion of forest were the result of TVS loss. Expansion of forest and shrub at the grasslands was the result of traditional agricultural practice reduction (Riecken et al., 2002). 
The aim of the study was to analyse the loss of the TVS in Krempna commune and to show the changes in villages and forest areas and also changes in ethnic, religious, cultural and economic components.

\section{Materials and methods}

The changes in land cover, dynamics of settlements, human population, religion and cultural aspects as the elements of TVS in the landscape within current borders of Krempna commune, in Jaslo county, Podkarpackie voivodeship in Poland, were objects of this study.

The number of householders and inhabitants based on the religious and ethnic composition was added for each of settlements in Krempna commune. Data from the years 1785 (Budzyński, 1993) and 1939 (Kubijovyč, 1983); maps from the years 1785, 1855 and 1939; and maps of 'WMS-Web Map Service, Geoportal' from the years 1965 and 2018 have been used. Changes in the number of villages and population dynamics for Greek Catholics, Latins and Jews for the year 1785 and Ukrainian ones in comparison with the number of Poles and Jews for the year 1939 were evaluated by applying ArcGIS 10.3 program. The corresponding layers in the ArcGIS 10.3 program (Urbański, 2010) have been completed. Ethnic and religious composition from the second half of the 18th century to the second half of the 20th century and the character of settlements distribution in Krempna commune have been evaluated based on the study of spatial distribution of settlements with the use of spatial statistics (spatial autocorrelation global Moran's test, standard deviational ellipse and mean center) executed in ArcMap program (Urbański, 2010), Scott, Janikas, 2010).

This study focuses on the role of the TVS to support sustainable landscape management. The TVS is defined by the land uses of pre-industrial cultural landscapes and a spatial structure with zones of land satisfying different cultural, social and economic needs (Elbakidze, Angelstam, 2007). The character of householders distribution in Krempna commune in the years 1785, 1855, 1939, 1965 and 2018 has been evaluated.

The changes in land cover based on maps and using the following indices (metrics) have been estimated and calculated on class level. Principles of landscape metrics (Forman, Godron, 1981) were applied in studies of different regions (Klaučo et al., 2013; Baran-Zgłobicka, Zgłobicki, 2012). For this study, three indexes (area metrics) have been chosen: class area (CA, in hectares); number of patches (NumP) and mean patch size (MPS, in hectares).

We respect present actual situation in Krempna commune using actual maps (2018) and conduct SWOT (strengths, weaknesses, opportunities, threats) analysis.

Analyses of published statistical data and recent original statistics were used to quantify the status and trends of economic and socio-cultural development of the Krempna commune. To evaluate the current TVS, we used spatial traditional village zoning structure (houses, gardens, fields, mowed grasslands, grazed grasslands and forests), traditional land use associated with cultural landscapes, types of natural resources used by local people and the goods and services produced by local land users.

\section{Results}

The analysis shows that the number of householders (Table 1) increased up to the year 1939 for Krempna commune. It can be concluded that the increase in the number of householders in the years 1785-1939 took place virtually for all localities, which could have been caused by the good economic development of TVS. The total number of householders increased from 915 in the year 1785 to 1,291 in the year 1855, and the highest value was obtained for the year 1939 with the result equal to 1,409 . The total number of householders decreased to four times in the year 1965 (349 householders) that confirm the loss of TVS in Krempna commune. The number of householders decreased to zero in Tychania, Ostryshne, Rozstajne and Svirzhova Ruska villages. Only few householders remained in Hrab, Vyshevatka, Ozhynna, Kotań and Zhydivske villages where State Agricultural Farms and prisons were created in 1950s-1970s. Families from other regions were settled in abandoned Lemko houses, for example, in Myt- 
sowa and Polana. But even after that, the total number of householders in Krempna commune decreased (Table 1) in the year 2018, which means that TVS has not renewed itself.

Calculations in the present work, conducted based on the data published by Budzyński (1993), are the evidence that in Krempna commune in the year 1785, Greek Catholic (Ukrainians) population amounted to $95.69 \%$, Latins to $2.60 \%$ and Jewish to $1.70 \%$ (Table 2).

However, it should be noted that Budzyński by the term Latins, except Poles, also meant Ukrainians, who spoke Ukrainian language, however, in order to participate in mass service went to the church (kościół). As a result, the term 'Latins' is incorrect. A correct manner is to identify two different terms: Roman Catholics (Poles) and Latins (Ukrainians), as it had been done before (Kubijovyč, 1983).

The previous is well illustrated on the example of villages such as Svirzhova Ruska and Polyany. In the year 1785, in the village of Svirzhova Ruska, there lived 266 Greek Catholics and 30 Latins according to Budzynski (1993). According to Kubiiovych, in the year 1939, there lived 475 Ukrainians and 5 Poles (Kubijovyč, 1983). In the village of Polyany, there lived 678 Greek Catholics, 115 Latins and 11 Jews in the year 1785 (Budzyński, 1993), whilst there lived 1,225 Ukrainians, 5 Jews and 60 Poles in the year 1939 (Kubijovyč, 1983). That decrease in the number of Poles in statistics for the year 1939 confirms the inaccuracy of data presented by Budzyński. Consequently, Ukrainian dominance is quite clear, meaning the dominance of Greek Catholics and Ukrainians (Table 2). It has been confirmed by the following data analysis in the year 1939 when $96.18 \%$ commune's population were Ukrainians, $3.31 \%$ were Poles and $0.51 \%$ were Jews (percentage of Germans was lesser than $0.01 \%$ and was not analysed).

$\mathrm{T}$ a b le 1. Number of householders in villages of Krempna commune in the years 1785-2018.

\begin{tabular}{|c|c|c|c|c|c|c|}
\hline \multirow{2}{*}{ No. } & \multirow{2}{*}{ Village name in English, Ukrainian and Polish } & \multicolumn{5}{|c|}{ Years } \\
\hline & & 1785 & 1855 & 1939 & 1965 & 2018 \\
\hline 1 & Tychania, Тиханя, Ciechania & 52 & 53 & 61 & 0 & 0 \\
\hline 2 & Hrab, Граб, Grab & 76 & 102 & 111 & 22 & 11 \\
\hline 3 & Huta Polyanska, Гута Полянська, Huta Polańska & 51 & 47 & 45 & 10 & 0 \\
\hline 4 & Kotan, Котань, Kotań & 37 & 53 & 52 & 5 & 54 \\
\hline 5 & Krampna, Крампна, Krępna & 74 & 108 & 101 & 25 & 89 \\
\hline 6 & Mystsova, Мисцова, Myscowa & 66 & 196 & 197 & 90 & 44 \\
\hline 7 & Ostryshne, Остришне, Ostryszne & 50 & 48 & 49 & 0 & 0 \\
\hline 8 & Ozhynna, Ожинна, Ożenna & 66 & 54 & 54 & 16 & 16 \\
\hline 9 & Polyany, Поляни, Polany & 134 & 171 & 185 & 93 & 43 \\
\hline 10 & Rozstajne, Розстайне, Rozstajne & 48 & 65 & 52 & 0 & 0 \\
\hline 11 & Svyatkova Mala, Святкова Мала, Świątkowa Mała & 35 & 43 & 54 & 18 & 18 \\
\hline 12 & Svyatkova Velyka, Святкова Велика, Świątkowa Wielka & 90 & 179 & 174 & 35 & 36 \\
\hline 13 & Vyshevatka, Вишеватка, Wyszowadka & 40 & 44 & 38 & 5 & 22 \\
\hline 14 & Svirzhova Ruska, Свіржова Руська, Świerzowa Ruska & 43 & 55 & 175 & 0 & 0 \\
\hline \multirow[t]{2}{*}{15} & Zhydivske, Жидівське, Żydowskie & 53 & 73 & 61 & 12 & 0 \\
\hline & Total & 915 & 1,291 & 1,409 & 349 & 333 \\
\hline
\end{tabular}


This situation demonstrates the dominance of Ukrainians before World War II. The placement ellipses analysis (Fig. 1) showed that in the year 1785, ellipse for Greek Catholics (black) is broader and covers a large area. This indicates a natural and more equilibrist distribution of Greek Catholics within Krempna commune. The ellipse for Latins has not been possible to create because Latins were living only in two villages (115 people in Polyany and 30 people in Svirzhova Ruska villages).

The mean center for Greek Catholics (black square) shows a more central distribution comparing to the mean center for Latins (grey triangle), which was located within $5.2 \mathrm{~km}$ to the North-East in comparison to the mean center of Greek Catholics. The ellipse for Jews (grey line) and mean center (grey hexagon) shows a similar central distribution comparing to the ellipse and the mean center representing Greek Catholics. It means common and the similar distribution of Greek Catholics and Jews.

In all settlements of Krempna commune (numbers on the figures correspond to the settlement number and settlement name in the table), Greek Catholics dominated in the year 1785. After the year 1785, the number of Greek Catholics increased (Blażejowskyj, 1995). In the year 1939 (Fig. 2), distribution ellipse for Ukrainians (black) did not change in compari-

$\mathrm{T} \mathrm{a} \mathrm{b} \mathrm{l} \mathrm{e} \mathrm{2.} \mathrm{Religious} \mathrm{and} \mathrm{national} \mathrm{distributions} \mathrm{of} \mathrm{settlements} \mathrm{in} \mathrm{Krempna} \mathrm{commune.}$

\begin{tabular}{|c|c|c|c|c|c|c|c|}
\hline \multirow{2}{*}{ No. } & \multirow{2}{*}{$\begin{array}{l}\text { Name in English, Ukrainian and } \\
\text { Polish }\end{array}$} & \multirow[b]{2}{*}{ Greek Catholics } & \multirow{2}{*}{$\begin{array}{c}1785 \\
\text { Latins }\end{array}$} & \multirow[b]{2}{*}{ Jews } & \multirow[b]{2}{*}{ Ukrainians } & \multirow{2}{*}{$\begin{array}{l}1939 \\
\text { Poles }\end{array}$} & \multirow[b]{2}{*}{ Jews } \\
\hline & & & & & & & \\
\hline 1 & Tychania, Тиханя, Ciechania & 305 & 0 & 7 & 425 & 5 & 0 \\
\hline 2 & Hrab, Граб, Grab & 450 & 0 & 9 & 680 & 0 & 0 \\
\hline 3 & $\begin{array}{l}\text { Huta Polyanska, Гута Полянська, } \\
\text { Huta Polańska }\end{array}$ & - & - & - & - & - & - \\
\hline 4 & Kotan, Котань, Kotań & 213 & 0 & 10 & 345 & 5 & 0 \\
\hline 5 & Krampna, Крампна, Krępna & 440 & 0 & 6 & 620 & 125 & 5 \\
\hline 6 & Mystsova, Мисцова, Myscowa & 1,023 & 0 & 10 & 1,310 & 10 & 0 \\
\hline 7 & Ostryshne, Остришне, Ostryszne & - & - & - & - & - & - \\
\hline 8 & Ozhynna, Ожинна, Ożenna & 395 & 0 & 3 & 360 & 0 & 0 \\
\hline 9 & Polyany, Поляни, Polany & 678 & 115 & 11 & 1,225 & 60 & 5 \\
\hline 10 & Rozstajne, Розстайне, Rozstajne & 280 & 0 & 8 & 320 & 0 & 10 \\
\hline 11 & $\begin{array}{l}\text { Svyatkova Mala, Святкова Мала, } \\
\text { Świątkowa Mała }\end{array}$ & 205 & 0 & 4 & 320 & 0 & 0 \\
\hline 12 & $\begin{array}{l}\text { Svyatkova Velyka, Святкова } \\
\text { Велика, Świątkowa Wielka }\end{array}$ & 528 & 0 & 14 & 820 & 5 & 5 \\
\hline 13 & $\begin{array}{l}\text { Vyshevatka, Вишеватка, } \\
\text { Wyszowadka }\end{array}$ & 240 & 0 & 0 & 245 & 0 & 5 \\
\hline 14 & $\begin{array}{l}\text { Svirzhova Ruska, Свіржова Руська, } \\
\text { Świerzowa Ruska }\end{array}$ & 266 & 30 & 6 & 475 & 5 & 0 \\
\hline 15 & Zhydivske, Жидівське, Żydowskie & 310 & 0 & 7 & 405 & 5 & 10 \\
\hline & Total & 5,333 & 145 & 95 & 7,550 & 220 & 40 \\
\hline
\end{tabular}

Note: - represents lack of data. 


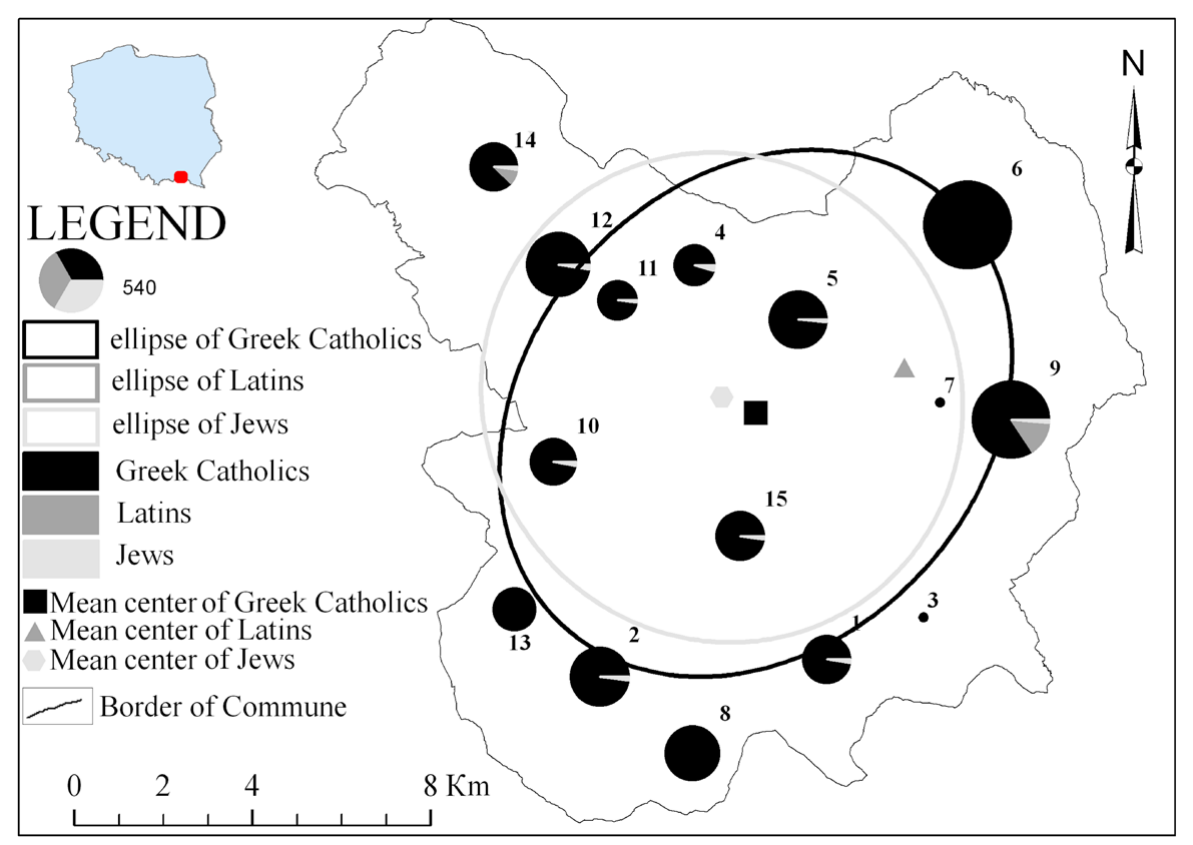

Fig. 1. Religious structure of settlements in Krempna commune in the year 1785.

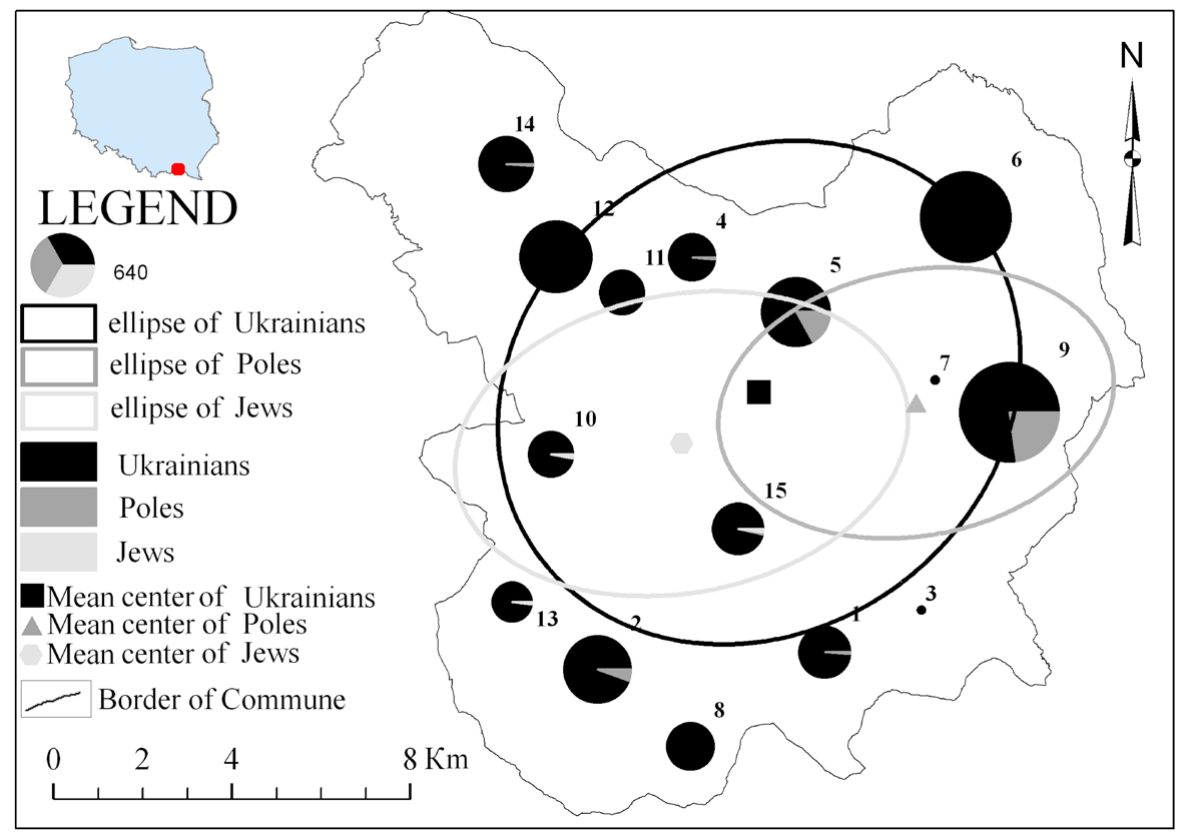

Fig. 2. National structure of settlements in Krempna commune in the year 1939. 
son with the ellipse for Greek Catholics in the year 1785. This tendency confirms the stability and durability of their settlement on the territory of Krempna commune.

In the year 1939, ellipse for Poles (dark grey) is smaller, elongated oval (Fig. 2) and distributed more to the North-East, comparing to the ellipse for Ukrainians (black). Ellipse representing Jews (light grey) moved to the West. Mean center (grey hexagon) representing Jews moved to the West and mean center representing Poles (grey triangle) moved to the East.

The analysis of Moran's test results leads to the conclusion that there was a random distribution of ethnic composition in the year 1939 for Poles and Jews. Only in case of Ukrainian population, the Moran's test has shown dispersed distribution (Index Moran's for Ukrainians $=-0.478664 ; \mathrm{Z}=-1.684100 ; \mathrm{P}=0.092162$ ) and confirmed that the probability of their distribution being a result of randomness is less than $10 \%$.

At the end of the 18th century, from the data of Josephine Metrics (1785) in the villages, the share of peasant arable land, meadows and pastures was quite high. For example, in the largest village of Polana, arable land occupied $833 \mathrm{ha}(33.8 \%)$ and meadows and pastures 1,612 ha (64.6\%). In smaller towns, as in Svyatkova Velyka, arable land occupied 573 ha (34.5\%) and meadows and pastures 801 ha (48.3\%), and in even smallest villages, as in Kotań, arable land occupied 241 ha (38.9\%) and meadows and pastures 302 ha (48.9\%). The share of forests varied from 21 ha (1.6\%) in Polana to $12.2 \%$ in Kotań and $17.2 \%$ in Svyatkova Velyka. The high share of arable land, meadows and pastures provided opportunities for the development of TVS until the year 1939.

The current traditional land use is not associated with cultural landscapes, and spatial traditional village zoning structure (houses, gardens, fields, mowed grasslands, grazed grasslands and forests) are destroyed. Types of natural resources are not used by local people, and the goods and services are not produced by local land users.

All settlements within Krempna commune area were destroyed after depopulation. Complete (100\%) destruction of householders occurred in villages such as Tychania, Ostryshne, Rozstajne, Ożenna, Zhydivske and Svirzhova Ruska. In many other settlements, the level of destruction reached more than $80 \%$. It should be noted that the level of destruction that occurred in 1950s was the highest and contributed to the loss of TVS. The comparison of the data from the years 1939 and 1965 showed a sharp decrease in the number of householders from 1409 in the year 1939 to 349 units in the year 1965.

Before World War II, the area of Krempna commune was densely populated. In the year 1785 , the density level reached 27.38 persons for $1 \mathrm{~km}^{2}$. In the year 1939, it reached 38.56 persons for $1 \mathrm{~km}^{2}$. According to the Central Statistical Office of Poland, in the year 2011, there were 2,004 persons (1,059 men and 945 women) on the area of $203.58 \mathrm{~km}^{2}$ and the density level decreased to 9.84 persons for $1 \mathrm{~km}^{2}$ (Statistics Poland, 2011). For the year 2018, the number of inhabitants in the commune decreased to 1,950. At present, the decreasing trend of the population in the commune persists.

In the year 1875, in Krempna commune, there lived 5,573 people. The majority of them, therefore, 5,333 of 5,573, were Ukrainian Greek Catholics. In the year 1939, there lived 7,850 people in the commune, including 7,550 of Ukrainian nationality. In the year 1965, the population of commune amounted to 1,250 people but with no Ukrainians amongst them. By analysing this situation, it is clear that without Ukrainians, Krempna commune has lost the TVS, which was rich in cultural, social and economic traditions. 
Before World War II, the character of traditional land use practices (two field rotating system, a combination of tillage and livestock products in one sector, crops rotation, mechanical devices for cultivation and weed control, protection of soil from erosion using special methods of ploughing) was completely dependent on the availability of local natural sources and kept in a sustainable and balanced relationship with the environment and minimal use of resources and energy of the region (Utrysko, 1984). Rural settlement livelihoods reflect spatial-temporal form of organisation of life. These settlements were inherent with traditional way of building for villages, features of wooden architecture, location and structure of agricultural land. Rural life was the basis of Ukrainian ethnographic identity.

After World War II, the Krempna commune was depopulated. The area of buildings, arable land, pastures and grasslands decreased. The structure of the land and forests has changed dramatically. The private forests and lands were transferred to the state property. Economic activities carried after 1950s were not always consistent with the management of traditional systems. These changes reduced the variety of structural elements such as hedges, gardens and individual trees in various areas of TVS. People who moved into the commune from low-lying areas till these days do not feel the spirit of that place (genius loci) and spirit of this mountainous area. The local use of natural resources should be considered as a weakness. There are no satisfying practices of traditional land use. As it was shown by SWOT analysis for Krempna commune, at present, there may be identified unfavourable conditions for its development, such as little access to historical documentation; no tradition and, therefore, connection with its origins; no indigenous population; lack of access to religious sites (other than Roman Catholic); inconvenient architectural forms as to the landscape conditions; and lack of work. In the destroyed villages, remaining tserkvas, crosses, Lemko houses and cemeteries are attractive for tourists at the present time.

Names of villages, which originally came from Ukrainian etymology, were changed into Polish: Kręmpna appeared instead of the name Krampna (from the name of ukr. «крам» goods), Ożenna instead of Ozhynna (from the name of ukr. «ожина» - blackberry), Ciechania instead of Tychania, Wyshowadka instead of Vyshevatka and Grab instead of Hrab. At the present time, on the territory of Krempna commune, there does not exist any link between generations. Villages that had been the core of Ukrainian TVS, together with tserkvas and chapels in the centre of village, roadside crosses and traditional householders, were lost. The Lemko Ukrainian tserkva that dominated on the area of the commune are considered as sacred and unique monuments of national wooden architecture, preserved in the centre of old Ruthenian traditions and became an element of Ukrainian and European cultural and religious foundation. Ukrainians have always preserved their cultural values (in every tserkva, except religious icons, there were also icons of Prince Volodymyr and Princess Olga to whom Ukrainians prayed and with whom they linked their confidence and hope). Tserkva, because of its form and building material, perfectly inscribed into the landscape and complemented it.

In Krempna commune, there were 13 tserkvas located in the following villages: Krempna, tserkva of Kosma and Damyan from the year 1782; Svirzhova Ruska, tserkva of Ivan Chrestytel from the year 1894; Hrab, tserkva of Kosma and Damyan from the year 1809; Svyatkova Velyka, tserkva of Archanhel Myhayil from the year 1757; Svyatkova Mala, tserkva of Archanhel Mychail from the year 1700; Mystsova, tserkva of St. Paraskeva from the year 1796; 
Polyany, tserkva of St. Ivan Zolotoustyj from the year 1900; Kotan, tserkva of Kosma and Damyan from the year 1800; Ozhynna, tserkva of Vasylij Velykyj from the year 1867; Rozstajne, tserkva of Kosma and Damyan from the year 1600; Tychanya, tserkva of St. Mykolaj from the year 1790; Vyshevatka, tserkva of (unknown name) from the year 1700; Zhydivske, tserkva of Voznesinnya Chrysta from the year 1828.

After World War II, there remained only 6 of the 13 tserkvas in Krempna commune in Svyatkova Velyka, Svyatkova Mala, Mystsova, Polyany, Kotan and Krempna that currently were taken over by the Roman Catholic Church (Luboński, 2015). Four tserkvas in villages of Hrab, Rozstajne, Tychanya and Zhydivske were destroyed in the years 1945-1947. Three tserkvas in villages of Svirzhova Ruska, Vyshevatka and Ozhynna were demolished in the post-war period - during 1950s. The area of settlements was sharply reduced (Fig. 3c and e) compared to the year 1855 (Fig. 3a; numbers on the figure correspond to settlement number and settlement name in the Tables 1 and 2). In the year 1965 and actual in the year 2018, the forests appeared on the site of the lost TVS with buildings, tserkvas, fields, meadows and pastures (Fig. 3d and f).

Metric analysis confirmed the destruction of settlement elements in Krempna commune. The CA of building area was 617.97 ha in the year 1785, 1,131.61 ha in the year 1855 and $1,174.02$ ha in the year 1939. CA building area decreased to 248.13 ha in the year 1965 and to 241.23 ha in the year 2018. The MPS index (represents average patch size for settlements) was 47.54 for the year $1785,80.83$ for the year 1855 and 71.60 for the year 1939. The MPS index decreased to 19.09 in the year 1965 and 18.17 in the year 2018, and this value points to the fragmentation of landscape mosaic.

On the other hand, CA for forest increased from 5,827.48 ha in the year 1855 to 7,268.62 in the year 1939, 15,465.20 in the year 1965 and 15,930.49 in the year 2018, and the MPS index increased too. In Krempna commune, an increasing trend of especially forest category was observed.

\section{Discussion}

On the present state of Krempna commune, landscape in the south-eastern Poland influences not only the geological processes (Kondracki, 2002) and climate by shaping the terrain and vegetation (Ziemońska, 1973) but also historical events that resulted in a reduction of population and their settlement area and the TVS lost. This, however, provoked the agricultural abandonment and intensified spontaneous forest succession processes in the landscape.

The analysis of settlements and population in Krempna commune presents domination of Greek-catholic and Ukrainians before World War II (WWII), which was also confirmed in the literature (Holly, 2014). The agricultural abandonment and intensive forest succession (Wolski, 2007; Klich et al., 2013), the process of depopulation of Ukrainians (Ardan, 2011) and the destruction of tserkvas in Lemkos and Bojkos region (Stępień et al., 2011) were also confirmed by studies from other parts of Carpathians. The analysis of the literature on TVS shows how such systems contribute to characteristic natural and cultural heritage (Agnoletti, 2006).

The loss of cultural heritage of TVS presented in Krempna commune has been recognised and promoted at a global level in a number of international agreements and programmes (World Conference, 1982; UNESCO, 1999; European Landscape Convention 2000; Antrop, 

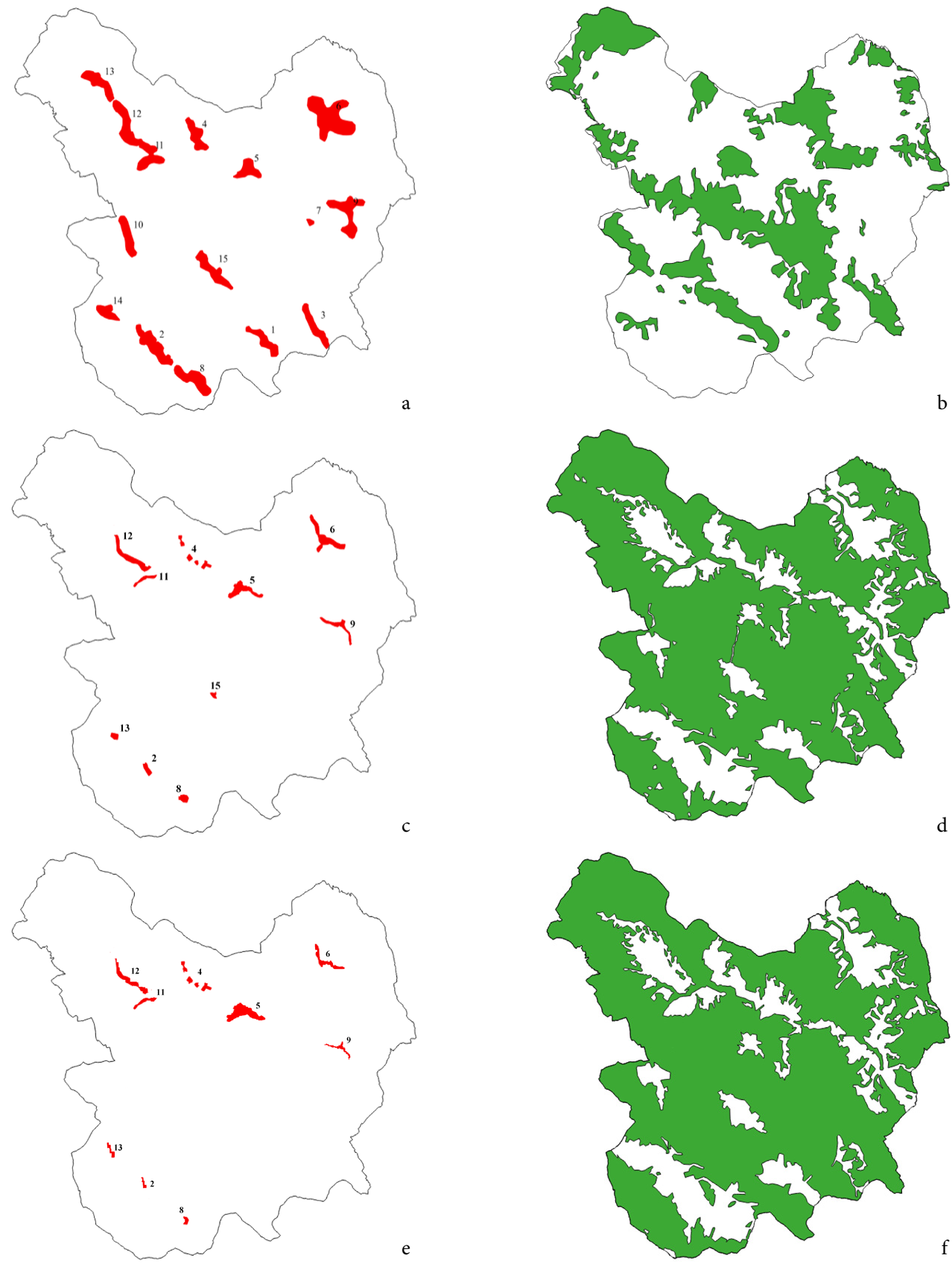

Fig. 3. Settlements (a, c and e) and forests (b, d and f) in the years 1855 (a, b), 1965 (c, d) and 2018 (e, f). 
2005). However, the TVS with its cultural landscape is often threatened by political decision, socio-economic and technological changes in agriculture, industrial forestry and particular nature conservation strategies (Agnoletti, 2006; Antrop, 2005).

After World War II, it is difficult to consider settlements as those that perform traditional role of rural systems. In fact, destroyed TVS had the traditional spatial structure, satisfying different needs of people. Research shows that lack of such system negatively affects the social and cultural aspects of sustainable management of the studied region. An increase in forestation and a decrease in land use (because of the decrease in number of population within that area) has been observed in the region. Eventually, natural succession process took advantage over the lack of human activity and land use practices (Ambrozy, Wika, 1998).

Objective historical information on the loss of TVS is also important for touristic purposes. Analysing the value of the landscape without Ukrainians, on the example of former Ruthenian (Ukrainian) Boryslavka village (currently nonexistent) in Sanotsko-Turchansky mountains (Fredropol commune), confirmed the sudden and radical changes in the characteristics of most landscape: the loss of its identity and the loss of spirit of the place (genius loci) of mountain terrain (Affek, 2011).

Historical statistical data is not always objectively shown in terms of ethnic and religious composition of the whole Galicia population (Kubijovyč, 1983) and the study area of Krempna commune. On the basis of this situation, it may be considered that evaluation of national origins and religious data is quite significant for a research within Krempna commune. As mentioned above, it is also important in terms of rural cultural landscapes. Such cultural landscapes are usually associated with TVS with centre-periphery zoning from houses, gardens, fields, mowed grasslands and grazed grasslands to forests (Elbakidze, Angelstam, 2007). Actually, the Krempna commune is one of the most forested regions in Poland (with $78 \%$ of forested land). The consequences of losing such a TVS require a more detailed study.

According to the European Landscape Convention (European Landscape Convention, 2000), it is a loss of social and cultural values on local and regional level. The convention defines landscape as a zone or an area in the perception of local residents or visitors where visual signs and symbols of the landscape are a result of natural and cultural factors, historical stratifications for a long time. The most important is its identity, tradition and material culture in the human landscape (European Landscape Convention, 2000). Next, according to the World Conference on Cultural Policies (World Conference, 1982), for example in Recommendation number 64 on the page 100 , we can see that folk culture, a fundamental component of a nation's heritage, should not be restricted solely to the productions of folk arts but should also take in aspects such as language, oral tradition, beliefs, celebrations, dietary habits, medicine and technology. Those elements were lost in the Krempna commune. The above-mentioned conducts to the degradation of the landscape, which constitutes a coherent entity, where natural and cultural components are closely interrelated.

\section{Conclusion}

The study has been performed within the border zone between Poland and Slovak Republic at the region of Krempna commune. We analysed the Krempna commune in terms of the 
changes in settlements and maps used for the analysis of changes in its structure by applying the ArcGIS program.

In Krempna commune, TVS was an example of sustainable co-existence of man and nature, natural and cultural heritage and social capital and was successful for centuries for achieving both common economic as well as cultural development of Lemkos people's in Poland with the traditional type of land use activity in cultural landscape and with the production of traditional goods and services by local land users.

The current land use is not associated with cultural landscapes, and spatial traditional village zoning structure is destroyed. The present land use clearly indicates that the present type of land use activity is not similar to the TVS. the present type of land use activity is not similar to the traditional, with reductions in diversity of all characteristics.

The change in land use observed in the study periods does not mean only the loss of agricultural land but also a decrease in the landscape diversity. It was a very negative phenomenon. Especially in a spatial context of the sustainable development of Krempna commune, that was an excellent region of harmony between human utilisation and landscape conservation.

The TVS was basic unit of the Krempna commune landscapes up to WWII. The analysis showed reduction in the number and area of settlement and loss of TVS. From the years 1939 to 2018, the area of settlements decreased in 4.9 times (CA decreased from 1,174.02 ha in the year 1939 to 241.23 ha in the year 2018). The MPS decreased from 71.6 in the year 1939 to 18.17 in the year 2018.

The Lemko Ukrainian tserkva - which dominated on the area of the commune, is considered as sacred and unique monuments of wooden architecture, preserved in the centre of old Ruthenian traditions and became an element of Ukrainian and European cultural and religious foundation - was destroyed (7 tserkvas).

Support of TVS (as a good indicator of sustainable landscapes) and socio-cultural functions and land use systems including fields, wooded grasslands and forests must be the milestones for sustainable development of this region.

\section{References}

Affek, A. (2011). Values of landscape abandoned by people. A case study of former Ruthenian village Boryslavka (in Polish). Prace Komisji Krajobrazu Kulturowego, 15, 148-160.

Agnoletti, M. (2006). The conservation of cultural landscapes. Wallingford, New York: CAB International.

Ambrozy, S. \& Wika S. (1998). Directions of succession of plant communities with Grej alder Alnus incana (L.) Moench on abandoned agricultural grounds in Western Bieszczady Mts. (in Polish). Prace Instytutu Badawczego Leśnictwa, Seria A, 855, 104-142. DOI: 10.2478/frp.

Angelstam, P. (2006). Maintaining cultural and natural biodiversity in Europe's economic centre and periphery. In M. Agnoletti (Ed.), The conservation of cultural landscapes (pp. 125-143). Wallingford, New York: CAB International.

Angelstam, P., Boresjö-Bronge, L., Mikusinski, G., Sporrong, U. \& Wästfelt A. (2003). Assessing village authenticity with satellite images a method to identify intact cultural landscapes in Europe. Ambio, 33(8), 594-604. DOI: $10.1007 / \mathrm{s} 13280-014-0510-2$.

Antrop, M. (2005). Why landscapes of the past are important for the future. Landsc. Urban Plann., 70, 21-34. DOI: 10.1016/j.landurbplan.2012.03.011.

Ardan, B. (2011). My Polyany. History of the village (in Ukrainian). Lviv: NTS. 
Baran-Zgłobicka, B. \& Zgłobicki W. (2012). Mosaic landscapes of SE Poland: should we preserve them? Agrofor. Syst., 85, 351-365. DOI: 10.1007/s10457-011-9436-x.

Blażejowskyj, D. (1995). Historical Šematism of the Eparchy of Peremyśl'. Lviv: Kameniar.

Bourguignon, H. (2006). Enhancing the role of forests in the socio-economic development of forested African countries. International Forestry Review, 8(1), 126-129. DOI: 10.1505/ifor.8.1.126.

Budzyński, Z. (1993). The population of the Polish-Russian borderland in the second half of the 18th century (in Polish). Przemyśl - Rzeszów.

Cramer, V.A., Hobbs, R.J. \& Standish R.J. (2008). What's new about old fields? Land abandonment and ecosystem assembly. Trends Ecol. Evol., 23, 104-112. DOI: 10.1016/j.tree.2007.10.005.

Denysjuk, O. (1938). The history of cooperative milk production in Lemkivshchyna (in Ukrainian). Cooperative Bulletin, 11, 4-7.

Elbakidze, M. \& Angelstam P. (2007). Implementing sustainable forest management in Ukraine's Carpathian mountains: the role of traditional village systems. For. Ecol. Manag., 249(1), 28-38. DOI: 10.1016/j.foreco.2015.10.020.

European Landscape Convention (2000). European Treaty. Council of Europe, 176, 1-7.

Forman, R.T.T. \& Godron M. (1981). Patches and structural components for a landscape ecology. Bioscience, 31, 733-740. DOI: $10.2307 / 1308780$.

Gil, A. (2004). Deportation of Ukrainians from Poland in 1944-1946 as a problem in actual Polish-Ukrainian relations (in Polish). Lublin: Wydawnictwo Instytutu Europy Środkowo-Wschodniej.

Holly, G. (2014). Sacral landscape transformation in the Polish-Slovak-Ukrainian border region during XIX-XXI century (in Polish). Monografie Bieszczadzkie, 15, 1-543.

Josephine Metrics (1785). Central State Historical Archives of Ukraine in Lviv. Description II, Storage units 13, 224, 233.

Klaučo, M., Gregorova, B., Stankov, M., Marković, V. \& Lemenkova P. (2013). Determination of ecological significance based on geostatistical assessment: a case study from the Slovak Natura 2000 protected area. Central European Journal of Geosciences, 5(1), 28-42. DOI: 10.2478/s13533-012-0120-0.

Klich, D., Gielarek, S. \& Antosiewicz M. (2013). Land cover dynamics in Western Bieszczady Mts between 19th and 20th century. Ekológia (Bratislava), 32(1), 95-103. DOI: 10.2478/eko-2013-0028.

Kondracki, J. (2002). Regional geography of Poland (in Polish). Warszawa: PWN.

Kubijovyč, V. (1983). Ethnic groups of the South-Western Ukraine (Galyčyna-Galicia) 1.1.1939. München: Logos.

Kuemmerle, T., Hostert, P., Radeloff, V.C., Van der Linden, S., Perzanowski, K. \& Kruhlov I. (2008). Cross-border comparison of post socialist farmland abandonment in the Carpathians. Ecosystems, 11, 614-628. DOI: 10.1007/s10021-008-9146-z.

Lieskovsky, J., Bezak, P., Špulerova, J., Lieskovsky, T., Koleda, P., Dobrovodska, M., Burgi, M. \& Gimmi U. (2015). The abandonment of traditional agricultural landscape in Slovakia - Analysis of extent and driving forces. Journal of Rural Studies, 37, 75-84. DOI: 10.1016/j.jrurstud.2014.12.007.

Luboński, P. (2015). The Bieszczady Mountains Guide (in Polish). Bosz.

MacDonald, D., Crabtree, J.R., Wiesinger, G., Dax, T., Stamou, N., Fleury, P. Gutierrez Lazpita, J. \& Gibon A. (2000). Agricultural abandonment in mountain areas of Europe: Environmental consequences and policy response. $J$. Environ. Manag., 59, 47-69. DOI: 10.1006/jema.1999.0335.

Masný M., Weis, K. \& Boltižiar M. (2017). Agricultural abandonment in chosen terrain attributes context - case study from the Polana UNESCO Biosphere Reserve (Central Slovakia). Ekológia (Bratislava), 36(4), 339-351. DOI: 10.2478 /eko-2013-0028.

MCPFE (2003). Vienna resolution 3. Preserving and enhancing the social and cultural dimensions of sustainable forest management in Europe. Wien: Fourth Conference on the Protection of Forests in Europe.

Muller, D., Kuemmerle, T., Rusu, M. \& Griffiths P. (2009). Lost in transition: determinants of post-socialist cropland abandonment in Romania. Journal of Land Use Science, 4, 109-129. DOI: 10.1080/17474230802645881.

Parrotta, J., Agnoletti, M. \& Johan E. (Eds.) (2006). Cultural heritage and sustainable forest management: the role of traditional knowledge. Ministerial Conference on the Protection of Forests in Europe. Liaison Unit Warsaw.

Pazur, R., Lieskovsky, J., Feranec, J. \& Otahel' J. (2014). Spatial determinants of abandonment of large-scale arable lands and managed grasslands in Slovakia during the periods of post-socialist transition and European Union accession. Applied Geography, 54, 118-128. DOI: 10.1016/j.apgeog.2014.07.014.

Riecken, U., Finck, P. \& Schroder E. (2002). Significance of pasture landscapes fornature conservation and extensive agriculture. In B. Redecker, W. Hardtle, P. Finck, U. Riecken \& E. Schroder (Eds.), Pasture landscapes and nature conservation (pp. 423-435). Heidelberg: Springer. 
Scott, L.M. \& Janikas M.V. (2010). Spatial Statistics in ArcGIS. In M.M. Fischer \& A. Getis (Eds.), Handbook of applied spatial analysis: Software tools, methods and applications (pp. 39-53). Berlin Heidelberg: Springer-Verlag.

Statistics Poland (2011). http://stat.gov.pl/en/databases/

Stevens, S. (1997). Conservation through cultural survival. Indigenous peoples and protected areas. Covelo: Island Press.

Stępień, A., Kozak, I. \& Kozak H. (2011). Three-dimensional reconstruction of landscape architectural object on example of a non-existing church at Beniowa (Western Bieszczady) (in Polish). Roczniki Bieszczadzkie, 19, 379-387.

UNESCO (1999). Evaluations of cultural properties. International Council on Monuments and Sites (ICO-MOS), WHC-99/CONF.209/INF.7. Marrakesh,Morocco.

Urbański, J. (2010). GIS in natural research (in Polish). Gdańsk: Wydawnictwo Uniwersytetu Gdańskiego.

Utrysko, M. (1984). Ethnographic research of Boikivshchyna between the two wars (in Ukrainian). LB (E). CH 2/40 (51), 1-15.

Van Vliet, J., De Groot, H.L.F., Rietveld, P. \& Verburg P.H. (2015). Manifestations and underlying drivers of agricultural land use change in Europe. Landsc. Urban Plann., 133, 24-36. DOI: 10.1016/j.landurbplan.2014.09.001.

Wolski, J. (2007). Transformations of the high Bieszczady Mountains rural landscape during the last 150 years (in Polish). Warszawa: IGiPZ PAN.

World Conference on Cultural Policies (1982). 26 July-6 August 1982 Final Report.Mexico City: Printed by Soregraph.

Ziemońska, Z. (1973). Hydrographic conditions in the Polish west Carpathians (in Polish). Prace Geograficzne Instytutu Geografii PAN. Warszaw: PAN. 